\title{
Technology Transfer Capability: development dynamics in higher education institutions
}

\author{
Cleverton Rodrigues Fernandes ${ }^{1, t(0)}$ \\ ${ }^{1}$ Universidade Federal da Paraíba, João Pessoa, PB, Brazil \\ André Gustavo Carvalho Machado $2, \Omega(B$ \\ ${ }^{2}$ Universidade Federal da Paraíba, João Pessoa, PB, Brazil
}

\section{ABSTRACT}

This paper aims to explain how the development dynamics of technology transfer capability occurs in Brazilian public higher education institutions. This study was guided by the dynamic capabilities perspective and some technology transfer models found in the literature. This research adopts the methodology of qualitative studies, in an interpretative and extended perspective, in two national reference institutions in an in-depth historical context with the purpose of expanding the theory. The results advance the findings in the literature regarding the characteristics of the technology transfer capability, distinguishing it from other capabilities, the influencing factors of its dynamism and a framework that reflects and clarifies the dynamic of its development. In terms of theory, the framework contributes to explain the functioning, the foundations and sustenance of a dynamic capability. From the perspective of practitioners, the framework explains how the intentionality of some human actors, with the influence of some internal and external factors, are paramount to found, sustain or bring change to the technology transfer capability.

Keywords: Strategic Management, Dynamic capabilities, Technology Transfer.

\section{INTRODUCTION}

Starting in the 1980s, several national governments were explicitly fostering the generation of new technologies in higher education institutions (HEIs) and the transfer of their respective outcomes into the productive sector (SANTOS; TOLEDO; LOTUFO, 2009; CLARIM, 2011). The assumption is that HEIs may reduce steps in the development of new goods, as well as mitigate the limitations of keeping a Research and Development sector (R\&D) in a firm (HELLMAN, 2007; MATHEWS; HU, 2007). However, despite its importance and the efforts made by governments, technology transfer is still a bottleneck in most of Brazilian public HEIs (ADES, 2013; CADORI, 2013; MCTI, 2015).

We can define technology transfer as the action of transferring technology originating in one organization to another or to other organizations, through the necessary comprehension, interpretation,

Corresponding author:

† Universidade Federal da Paraíba, João Pessoa, PB, Brazil

E-mail: cleverton.ufpb@hotmail.com

$\Omega^{\Omega}$ Universidade Federal da Paraíba, João

Pessoa, PB, Brazil

E-mail: agcmachado@gmail.com

Received: 06/15/2017.

Revised: 01/30/2018.

Accepted: 03/22/2018.

Published Online: 07/13/2018.

DOI: http://dx.doi.org/10.15728/bbr.2019.16.1.1 
evaluation and absorption of technology in their practice. Although this may occur informally (KATHOEFER; LEKER, 2012; CLOSS et al., 2013), in this study, we only consider as valid technology transfers upon the existence of contracts, for they demonstrate the formality, intention and action of the individual who has the power of decision. Therefore, technology transfer may comprise the process of licensing, tech-base incubation, or transfer of ownership to a third party to exploit a patent applied or obtained in the country (MCTI, 2015).

Unlike the current view of technology transfer that we find in the investigated literature, which compares it to one activity, action, process, fact, step or target, this study assumes that technology transfer is a dynamic compound of intentional and organizational actions amid routines, competencies, resources, and capabilities to transfer technology. Thus, technology transfer acts as a dynamic capability and can generate, at least, differentiation between comparable organizations. Dynamic capability is herein understood as the "the capacity of an organization to purposefully create, extend, or modify its resource base" (HELFAT et al., 2007, p. 4). Thus, we rely on the premise that an organization that can successfully transfer technology can be considered the owner of Technology Transfer Capability (TTC).

In this perspective, the dynamic capability of technology transfer has the potential to contribute directly or indirectly to incrementing the organizational performance. Directly, in that the reconfiguration of the process may lead to a more efficient flow of technologies developed within an organization to other organizations, generating revenue from its use. Indirectly, by fostering new research, partnerships, and attracting new researchers due to the improved institutional image.

In considering this, we synthesize the research problem into the following question: how does the development dynamics of the technology transfer capability occur in Brazilian public HEIs? Therefore, the central objective is to explain how the development dynamics of the technology transfer capability occurs in Brazilian public HEIs. More specifically, we investigate the characteristics, the development factors and the components of the technology transfer capability.

Despite the importance of researchers and firms to the process of technology transfer, this study focused on Brazilians Nuclei of Technological Innovation (NTI), equivalent to the Technology Transfer Office (TTO), where transfers of formal and legally acknowledged technologies occur between public HEIs and the productive sector. Therefore, this investigation is limited to two institutions that have an established and structured NTI, with actual experience in negotiating technology with public or private firms through a contract, namely: Universidade de São Paulo (USP) and Universidade Estadual de Campinas (UNICAMP).

The results of this study advance the findings in the literature in that we present, for the first time and based on empirical studies, a framework that reflects the development dynamics of the TTC and clarifies the interactions of its elements with both internal and external factors to the HEIs.

We divide this paper into five parts. After this introduction, we present the theoretical basis and, the adopted methods thereafter. In the sequence, we synthetically show and analyze the results of the investigated cases, and, finally, we set out the conclusions.

\section{TheORETICAL BASIS}

In general terms, technology transfer may be regarded as a term that relates to a specific and limited diffusion of technology with innovative market-driven aspirations. Technology transfer is usually in a pre-competitive phase and involves strategic, formal, planned and 
BBR

16,1

intentional issues, and is more specific than knowledge transfer, which is much broader (GOPALAKRISHNAN; SANTORO, 2004).

There are some primary reasons for technology transfer from universities, among which we are able to list four (YOUNG, 2005): facilitate the commercialization of research results for the public good; reward, retain and recruit faculty; induce closer ties to industry; and, generate income and promote economic growth. The action of technology transfer may be furthered by the NTI, which are favorable environments for the management, protection and transfer of university inventions, and are the main interlocutors between the HEIs and the productive sector (SANTOS; TOLEDO; LOTUFO, 2009). The technologies generated in the academic setting are therefore, passed on to the productive sector, thus contributing to the creation of new resources and innovative firms (COZZI et al., 2008; GARCIA; GAVA, 2012).

In turn, there are several models available in the literature on the intrafirm technology transfer. For example, Szulanski (2000) relies on a procedural view of transfer considering steps, phases and difficulties involved. Rogers, Takegami and Yin (2001) show a linear process of technology transfer following these steps: research expenditures or investment, invention or creation disclosure, patent applications, technology licenses execution, technology licenses yielding income; technology royalties; and, the resulting wealth. The Stage-gate model, proposed by Jagoda, Maheshwari and Lonseth (2010), divides the transfer process into the stages of initiation, planning, execution and evaluation, while Carvalho and Cunha (2013) present nine indicators across three transfer stages: alpha, beta and gamma.

Takahashi and Sacomano (2002), in turn, represent the transfer projects in the pharmaceuticals sector as some success factors: technology, absorption and managerial technologies, apart from the transfer modes and performances accomplished in the process. Meanwhile, Bercovitz and Feldmann (2006) underscore the broader relations of innovation that occur between universities and firms. In addition, there is a conception of transfer as a process that would start in the industry or in academia as an innovation per se, that goes through static validation and then dynamic validation up to the release of the technology. (IVARSSON; GORSCHEK, 2009).

Among the theories available upon which to base this study, the Dynamic Capabilities Perspective has been satisfactory for allowing the observation of the technology transfer phenomenon in a "meso" level, that is, capable of considering the organizational idiosyncrasies; however, without being restricted to the individual level. Such perspective has enabled the identification of generic, reproduceable and comparable factors that could compose a "meta-routine". Thus, we understand routine as a set of behavioral capabilities, i.e., the result of the transformation of collective skills and habits through the organizational strategy, structure and conjuncture. (MILAGRES, 2011).

As identified in the literature (DANNEELS, 2002; ZAHRA; SAPIENZA; DAVIDSSON, 2006), capabilities can be operational (WINTER, 2003), which would be first-order dynamic capabilities (COLLIS, 1994), or dynamic (TEECE; PISANO; SHUEN, 1997; EISENHARDT; MARTIN, 2000; HELFAT et al., 2007). The term "dynamic" refers to the change in the resource base, to the renewal of resources (AMBROSINI; BOWMAN, 2009).

Dynamic capabilities are based on the arguments of Schumpeter (1961) about the process of creative destruction (TONDOLO; BITENCOURT, 2014), and have a conceptual structure founded in different theories: the behavioral theory of the firm (CYERT; MARCH, 1992), especially when it comes to singularity (as to the aspirations, knowledge and decisions of organizational actors) and the notions of adaptation (AUGIER; TEECE, 2008); 
the evolutionary theory (NELSON; WINTER, 2005), with a special focus on the role of routines in the process of organizational growth and change (AMBROSINI; BOWMAN, 2009); and the Resource-based View (WERNERFELT, 1984; BARNEY, 1991; PENROSE, 2006), whose main elements are heterogeneity and resource immobility.

In addition, Augier and Teece (2008) draw focus to the complementarity between transaction cost theory (WILLIAMSON, 1985) and dynamic capabilities. Whereas the former contributed to explain organizational design issues, it deals with existing resources and concentrates on opportunism and asset protection, the latter investigates how resources can be incorporated and developed over time to respond to environmental changes, exploring opportunities and creating value.

The Dynamic Capabilities Perspective has several frameworks. An example is that which Teece, Pisano and Shuen (1997) propose, which represents the previous paths, as is the case of history and previous investments, which lead to the current positions of a firm, including both the tangible and intangible assets. Consistent with the evolutionary theory, the processes and the dynamic capabilities would change the current positions and would conduct the firm to new performance, paths and positions. Eisenhardt and Martin (2000), on the other hand, describe the dynamic capabilities as processes that a firm may use to gain, integrate, reconfigure and release resources, resulting in new resources and new resource configurations. The view that the dynamic capabilities would generate new "things", seems to have inspired Lawson and Samson (2001) in their innovation capability framework.

The issue about "how" the capabilities are developed are first and more conspicuously highlighted in the conceptual model by Zollo and Winter (2002). The authors explicitly consider the rules of intentionality in the learning process, distinguishing between semiautomatic learning, or learning through practice, and the types of deliberate learning, such as knowledge articulation and codification. Helfat and Peteraf(2003), complementarily explicit, through a framework, the stages of evolution of the dynamic capabilities.

Zott (2003) explores the relations between the dynamic capabilities and differential performance provided by the adopting firms. The model suggested by the author focuses on the endogenous choices firms make, which would include selecting and employing specific resources and combined resources, by imitation or experimentation, to generate favorable alternatives of resource configurations.

Wang and Ahmed (2007) suggest that dynamic market factors influence the dynamic capabilities, which are made of component factors, with common features, and by underlying processes, specific of each firm. Next, such capabilities interfere with the strategies and, indirectly, with the development of new capabilities and the organizational performance.

Teece (2007) presents one concept of the foundation of dynamic capabilities. The author explores more deeply the fundamentals of such capabilities, addressing previous paths and asset base, routines, identification of opportunities, investments and seizing opportunities, recombination and reconfiguring and, lastly, the new paths and asset base of and resulting performance.

The proposal by Romme, Zollo and Berends (2010) is a little more complex when compared to those previously listed and models a general dynamic, which is capable of exploring the basic tradeoffs and the ambiguities when deciding on investing in deliberate learning processes to promote the development of dynamic capabilities. Meanwhile, Gebauer (2011) highlights the unfolding and the relations between operational capabilities, dynamics and innovation management. 
BBR

16,1

Finally, the study by Wilden et al. (2013) addressed internal fit (organizational structure) and external fit (competitive intensity), which shape dynamic capabilities to achieve the superior organizational performance. The results obtained by these last two authors reinforce that one of the main attributes of dynamic capabilities is, in fact, to promote a specific outcome that helps an organization remain healthy; more importantly, that the goals be achieved. In case of universities, this fact may be associated to the actual technology transfers.

\section{Methodological Procedures}

To answer the research question herein proposed, we adopted qualitative studies, in an interpretative perspective (BURREL; MORGAN, 1979; MERRIAM, 2009), of two extended cases in an in-depth historical context with the objective to reconceptualize and prolong the theory (BURAWOY et al., 1991; BURAWOY, 2009). We selected the cases based on the Folha University Ranking on innovation (Ranking Universitário Folha) (RUF, 2015): USP, ranked first, and UNICAMP, ranked second, for being reference institutions regarding patent protection and technology transfer in Brazil (CLOSS; FERREIRA, 2012; DIAS; PORTO, 2013; 2014).

We chose these two institutions - which have a cutting-edge technology production and well-structured NTI - because the authors assumed that they already had fully developed TTC. Since the study focused on knowing how the development of the said capability occurs, it would make no sense to dedicate efforts on researching other average-profile Brazilian public HEIs that did not have a well-structured NTI or was not very active concerning technology transfer.

As for the approach used in this research, we chose to use the extended case, which involves four attributes: visiting the site, extended periods of time, moving from "micro" to "macro", and building on preexisting theories (BURAWOY, 2009). The said method is characterized by the cycles of confrontation between data and theory in each iteration, directing the analyst to additional data and drawing on additional concepts and theories. (DANNEEL, 2010).

We chose the technology transfer events based on the existence of contracts, as well as access to data that would allow finding the common thread of events, facts and actions. We chose three for each case: the first between the years of 2004 and 2007, the second between 2008 and 2011, and, finally, the third between 2012 and 2015. Thus, the stories that were recalled and didactically structured and developed from each particular context made up each extended case. That is, in this study, we did not set off from a case and divided it into contexts, but, rather, we set off at each historical context; when we added the three of them up, they formed the USP or UNICAMP case.

We collected the data between the months of March and May 2016. Based on Danneels (2010), the first step of data collection retrieved the information available on the HEIs' websites, as well as from their NTI. Thereafter, we visited the facilities and the staff of the NTIs and the sectors in charge of technology transfer (BOEHM; HOGAN, 2014). In this second moment, we conducted systematic observation (GRAY, 2012) to help understand the actions taken by the HEIs.

The third step involved collecting the technical documents, such as processes, meetings minutes, projects, memorandums, letters, contracts (either published or unpublished), statements, non-disclosure agreements, among others that were directly connected to the research theme and are not usually made available to visitors. In this step, we took only the documents that did not have a classified status. 
The fourth step involved notes, photographs of the visits, retrospective interviews and in-depth interviews (KVALE; BRINKMANN, 2009; GODOI; MATTOS, 2010). The interviews were semi-structured involving the principal decision-makers either directly or indirectly connected to the NTI of each of the Brazilian public HEIs investigated. In this sense, we interviewed five people at USP and four at UNICAMP. The principal dimensions addressed in the interview script involved: external environment, policies, market and society; position and international model employed; and the structure of the meta-routine, funding, and previous paths to success (detection); mainstream and newstream relations (seizing); and dynamic capacity evolution (transformation).

For the analysis, we adopt both the extended case method (BURAWOY et al., 1991; BURAWOY, 2009) and the discourse analysis (GADET; HAK; MARIANI, 1997). Initially, we condensed the contexts concerning the three time frames (2004-2007; 20082011; 2012-2015) of each of the cases independently (within case), with the aim to build up a standard on a par with the theory. We compare each standard to the others (cross case) and, as such, we analyze them based on the literature to build a framework that would demonstrate the characteristics and factors involved in the development of the TTC. To analyze the discourse, we adopted three discursivization procedures (actorialization actor identification and formation -, spacialization, and temporalization) and two basic mechanisms of the study of enunciation marks (débrayage and embrayage).

\section{Results Presentation and Discussion}

Although USP is 32 years older than UNICAMP, the latter pioneered in starting its NTI in 2003. In addition, despite USP's scientific and technological force, with 55,659 papers in its catalogue (SIR, 2015) and 890 cases of patent protection, UNICAMP has more than doubled USP's technology transfers between 2004 and 2016. On the other hand, we found that, during the process of development of the technology transfer capability, both HEIs had similar behavior and characteristics, which allowed putting up a framework that depicts the dynamic of this event, as shown in Figure 1 below.

The researchers involved in technology transfers begin their research analysis by detecting the opportunities, which are modeled on the internal factors, resources, competencies, routines and capabilities (RCRC) available, and the external factors. Up to this moment, as highlighted by the interviewee appointed as UNDP00, there is little involvement of the NTI in terms of suggesting the direction of researches, because "We cannot just tell the researcher: 'look, you [must] study this because this is what the market wants!'”. That is, the NTI cannot influence researchers as to their research interests. With this in mind, we considered that the TTC, at this moment of the meta-routine, would still be reduced.

After communicating the research outcomes to the NTI or TTO, the identification of opportunities (sensing), as highlighted by Teece (2007), is intensified, therefore, when considering the technological novelty and the socioeconomic adherence, in line with Wilden et al. (2013), we are able to adjust for the competitive intensity and the ongoing transfer structure. Thus, the standard procedures in place to regularize, protect, verify the transfer potential, i.e., the mainstream, and find industrial partners, are faced with the demands and specialties of the new technology disclosed. Consequently, according to Lawson and Samson (2001), RCRC go through changes (renewals, recombining and reconfiguring) and newstream innovations, which generate transformations in the TTC compound.

After renewing, recombining and reconfiguring the TTC elements, also involving a possible component creation or elimination, comes the incorporation or formal institutionalization, by codification, of this new compound, which, then, would return to 
BBR

16,1

7

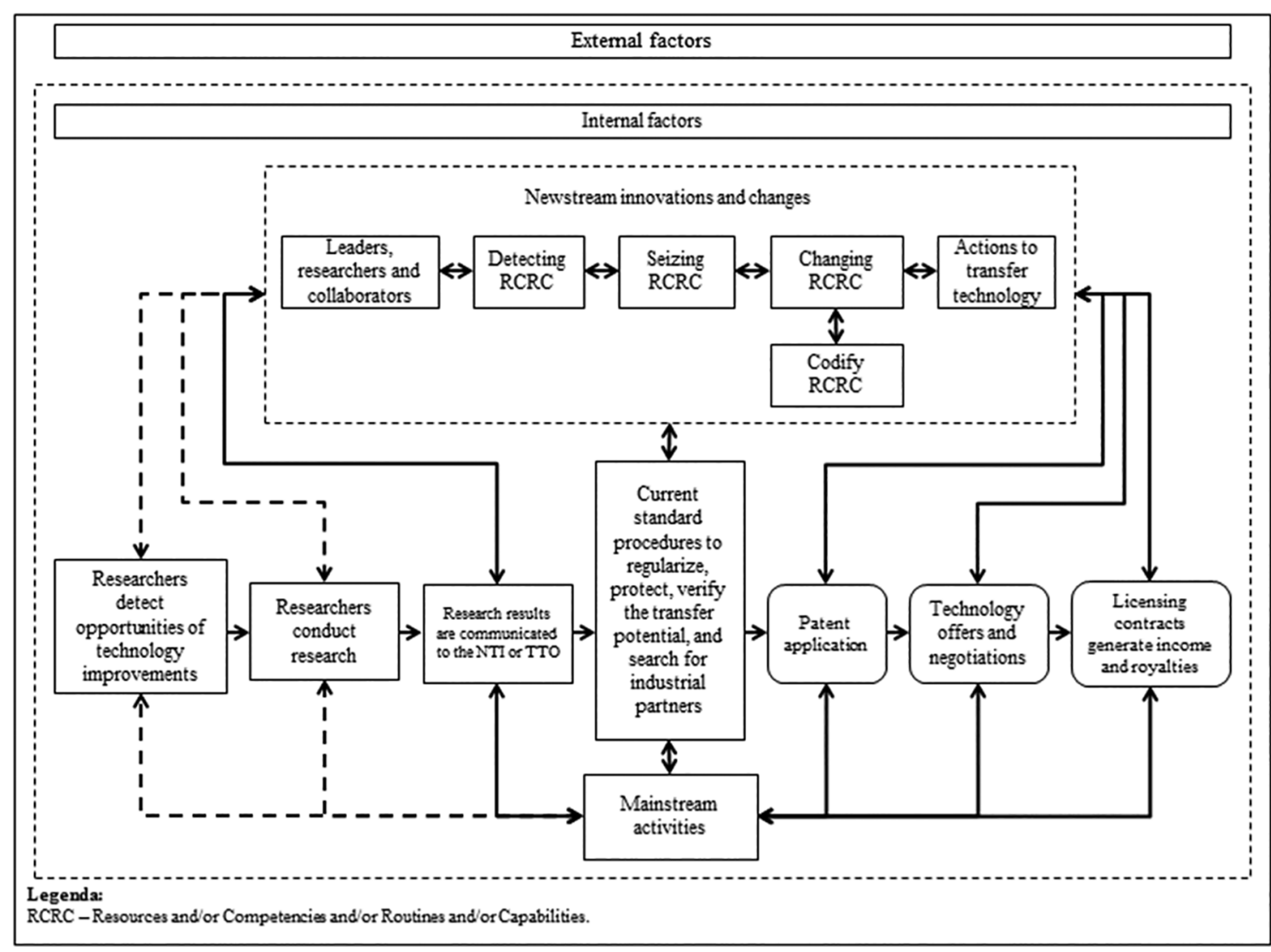

Figure 1. Framework: TTC development dynamics. Source: The Authors.

the state of mainstream activity, and would also be replicated or disseminated, as suggested by Lawson and Samson (2001) and Pavlou and El Sawy (2011). It is a cyclical movement, which is, somehow, close to that of Zollo and Winter (2002), i.e., the capability in place is scrutinized through internal and external stimuli as well as the interest of the very leaders and collaborators, who would conduct an evaluation and, finally, the legitimation after the changes. The renewed dynamic capability would be routine, formalized and shared, awaiting a new development cycle to begin.

Even if the capability development cycle has not been concluded, applying for intellectual property protection (patent), the offer and negotiation and the resulting licensing contract, which could generate income and royalties would finalize the meta-routine. In short, considering the evolution over time and space, the mainstream activities would be in a first position that would be then thought over by the leaders, researchers and collaborators, based on internal and external factors, to reach new objectives and goals strategically set out, or resulting from emerging decisions, in a movement with mainstream characteristics, which would, then, be the second position. Finally, the third position would be the new temporary crystallizations of the new actions, activities, compound and, consequently, of all the meta-routine that would once again have mainstream characteristics.

Through the interviews, document analysis and direct observations, we are able to raise a set of resources, competencies, routines and capabilities (RCRC) that are common to both institutions. The main resources regard location, equity capital, funding, equipment, public and private financing, leaders, technology portfolios, internal regulations on technological innovation, organizational culture, accumulated organizational knowledge and information systems. 
On the other hand, we identified individual characteristics, such as the persistent use of MSExcel spreadsheets and physical documents at USP, which demonstrated limited evolution until the adoption of "Inteum" and the creation of the "e-Convênios" and "Conexão USP" software. The latter program is equivalent to the system named "Competências UNICAMP". UNICAMP, in turn, adopted a more robust information system along with the development of the TTC, as was the case of CACOM and MANTIS, whose systems were improved and gathered into SISE. The collaborators treated the size of USP as a resource that motivated the creation of the TTC, whereas at UNICAMP it had more to do with the view of the first leaders.

As for the competencies, those that were identified in both institutions are: scientific research and technology development, specialized knowledge of the inventions in $\mathrm{PhD}$ level, patent drafting, anteriority search, invention-related technical and economic viability studies, negotiating, entrepreneurship and technology valuing. USP was found to have collaborated in studies of technical and economic viability conducted by third parties, whereas UNICAMP preferred to conduct these viability studies in campus. UNICAMP even demonstrated other relevant competencies, which were not clearly evidenced at USP, as was the case of the technology prospection competency, the collaborator valuing competency, process management and drafting open announcement.

As for the routines, those that in both institutions we identify the following : inventive communication routine, internationalization, communication or diffusion of information internally and externally, research and development, decision-making, standardized operational procedures, process and practice reformulation, training, and mapping competencies. We find that other competencies to have subtle differences at either institution, as is the case of the continued monitoring routine (benchmarking) at USP, which is rather similar and related to the continuous adjustment and improvement and the continued monitoring at UNICAMP.

The project management routine is well emphasized at UNICAMP; in addition, UNICAMP adopted internal routines for organizational climate verification and 180-degree assessment of collaborators. USP, in turn, tested the classification routine through the ABC Analysis; however, this routine did not persist and was abandoned early, due to the limited personnel dedicated to the Technology Transfer Board.

We identified several capabilities as composing and acting on behalf of TTC and for both Brazilian public HEIs analyzed. The equally verified capabilities are: communication capability, research capability, relational capability, service providing capability, organizational capability, leaning to learn capability (COLLIS, 1994), managerial capability (RINDOVA; TAYLOR, 2002), adaptation capability (ADNER; HELFAT, 2003), conception and knowledge generating capability (McKELVIE; DAVIDSSON, 2009), leadership capability, innovation capability (LAWSON; SAMSON, 2001), absorptive capability (TAKAHASHI; SACOMANO, 2002; WANG; AHMED, 2007). The last three capabilities had quite an impact on both HEIs over the years 2004-2015, and for the development of the TTC.

Nevertheless, some capabilities that compose the TTC were more evident in one of the two HEIs. For example, at USP, we verified the following capabilities: idea generation, relational learning, and internationalization. At UNICAMP, in turn, we found other capabilities more clearly, such as updates management, integration, coordination, and technology offer. 
BBR

16,1

9

During the research, we also verified internal and external factors that either favor or limit the development of the TTC. We found that the endogenous and exogenous dynamism to the institution interfered in several ways since the creation, evolution or retrogression of the said dynamic capability. This way, we consider the varied environmental influence sui generis, according to the case under analysis; however, we can find some patterns.

The internal factors identified in both HEIs were: leaders action, substantive capabilities, organizational knowledge, strategic management, project management, geographic location, learning processes, and operational processes. They both constituted and modified the composition of the TTC and were transformed by it over time in the form of RCRC. The understanding that the internal factors interfere with the appearance and development of the dynamic capabilities, indeed, date back to the contributions by Teece, Pisano and Shuen (1997), when they deal with the previous paths; to the suggestions by Eisenhardt and Martin (2000), when they address resources; and Lawson and Samson (2001), who discuss resources, raw materials, products, processes, systems and business flows.

Strictly speaking, amongst the internal factors, geographic location presented significant differences between the NTI investigated. At NTI-UNICAMP, there was no change that would jeopardize or abruptly favor the TTC. At NTI-USP, oscillations were both harming and favorable. Broadly speaking, the location was equally favorable to both the Brazilian public HEIs investigated. This occurred because of the spillover effect. Both USP and UNICAMP were always favorable to the continued development of the TTC. The operational or substantive capabilities, in turn, were the most cited both as elements and as a type of induction factor of creation and development of dynamic capabilities, along the line with the understanding of Zahra, Sapienza and Davidsson (2006); Wang and Ahmed (2007); Gebauer (2011); Pavlou and El Sawy (2011); and Salunke, Weerawardena and McCollKennedy (2011).

The external factors that influenced or limited the advances of the TTC in both the NTIs are: intellectual anteriority, innovations, market, public policies and society. Under the perspective of the intellectual anteriority, between 2004 and 2007, in both HEIs, the technological novelty originated from previous technologic knowledge and international models of technology transfer available in academia and the market. Between 2008 and 2011, the technological novelty at USP originated from technological knowledge available both in academia and social needs, rather than market needs, as in the first period. At UNICAMP, it involved academic, market and social needs. Between 2012 and 2015, in turn, the UNICAMP Innovation Agency (INOVA UNICAMP) was more influenced by the transfer model of the University of Cambridge and the Business Model Canvas (BMC), whereas at NTI-USP the technology novelty, similar to UNICAMP, comprised of the academic availability, the market and social opportunities and needs.

Innovation was another external factor that we verified. Between 2004 and 2007, NTI-UNICAMP adopted the I3 software, whereas between 2012 and 2015 Agência-USP incorporated the software "Inteum" and "Plataforma iTEC", while INOVA-UNICAMP adopted the Questel Orbit system and "Somos". Thus, we noticed innovative investment from the external setting at both the NTI, which favor the TTC improvement. Intellectual and financial support, previous experiences and relationships that are geographically close to the market also influenced the evolution of the TTC at both institutions. However, between the years of 2012 and 2015, the fast internet market growth, corporate support for $\mathrm{R} \& \mathrm{D}$ and consultancy to improve technology supply profiles were key factors that favored the development of TTC at UNICAMP. 
The public policies also led to the creation and the evolution of TTC at both Brazilian public HEIs. In the first period, Laws no. 9.279/1996 and no. 10.973/2004 and Decree no. $50.504 / 2006$ fostered the development of the transfer capability at USP. In addition, the financial support to research and innovation by CNPq, FAPESP and FINEP, for example, were essential for maintaining the body of internal and external collaborators (researchers) at NTI-USP. On the other hand, hiring scholarship holders for a limited time had a negative impact on both the technology transfer service providing for this NTI and the development of TTC.

The contract oscillation of scholarship holders was also a problem at NTI-UNICAMP, mainly in the first period. In addition to this restraint is the promulgation of the Decree no. $5.563 / 2005$, which hindered exclusive licensing. Nevertheless, legislations such as Law no. $10.973 / 2004$ were favorable to UNICAMP as much as they were to USP.

In the second period, public policies interfered very similarly in both institutions. Thus, Complementary State Law no. 1.049/2008, State Decree no. 54.690/2009, the financial support of research funding offices (e.g. FAPESP, FINEP and CNPq) and the new civil service entrance examinations to hire new permanent staff for the NTI were favorable to the development of the TTC. In the third period, the National Broadband Program (Programa Nacional de Banda Larga, in Portuguese) and the financing by FAPESP were evident at UNICAMP, whereas at USP, in addition to this support by the funding offices, FAPESP's PIPE projects, the support from CNPq and FINEP, the "Plataforma iTEC" and the "Programa Pitch GOV SP" contributed to build bridges between USP and Brazilian firms, through training collaborators of NTI-USP and by maintaining the scholarships and, consequently, the TTC development.

Society also stimulated realizing the TTC at both NTIs. This stimulus was much related to the technologies at each analyzed period. In the first period, hospitals' demands for efficient low-cost human skin regenerator, and the entrepreneurial stimulus of USP's geographical surroundings favored the development of TTC. Meanwhile, at NTI-UNICAMP this development was related more to the speed of the TTC meta-routine and was the result of demands of diabetics for a cheaper, more beneficial medicine, apart from the entrepreneurial stimulus and innovative geographical surrounding of the said HEI.

The demands for non-aggressive, non-flammable, non-corrosive, biodegradable, sustainable disinfectants being used in sensitive settings and the stimulus to innovative entrepreneurship in the region favored the development of TTC at NTI-USP. At UNICAMP, the TTC speed was even more improved through social demands for a more effective varnish with a better cost-benefit, for treating dental cavities. In the third and last period, the improvements at the USP Nucleus were stimulated by the social search for a method to find xylanase enzymes specific for the biowhitening of cellulose pulp that would reduce costs and environmental impacts.

All things considered, the dynamic capability of technology transfer contributed to increase the adherence between technologies developed within the HEI and market demands. As a consequence, managers and researchers sensed the need for new resources, competencies, routines and capabilities, or even reconfigure those already existing, to explore opportunities, improve the institutional image and improve the financial outcome deriving, for example, from royalties.

In this matter, between the years of 2004 and 2015, USP and UNICAMP earned royalties worth 6,394,350.00 BRL and 6,283,350.95 BRL, respectively, according to the annual reports published by each institution. These finding are in consonance with Teece, Pisano 
BBR

16,1

and Shuen (1997), Eisenhardt and Martin (2000), Zott (2003), Teece (2007), Wang and Ahmed (2007) and Wilden et al. (2013), who highlighted the potential of the dynamic capabilities to improve the organizational performance.

\section{Conclusions}

This research relied on the premise that if one organization manages to transfer technology, it will possibly possess Technology Transfer Capability (TTC). The results of this study confirm the initial assumption that the technology transfer is a dynamic compound of intentional and organizational actions amid resources, competencies, routines and capabilities (RCRC) to transfer technology and is capable of generating, at least, differentiation between comparable organizations.

In investigating the TTC in the two, most relevant and acknowledged Brazilian public HEIs, allowed us constituting, for the first time, a meta-routine (TTC framework) which explains the workings and dynamics of this capability, and broadens the understanding of the foundations and sustenance of a dynamic capability. We found that the TTC metaroutine starts at the identification of an opportunity regarding technological improvements found by the researchers who would begin with the research. The research outcomes are duly communicated to the institutional NTI, which will then start the standard procedures to regularize, protect, verify the transfer potential, and search for industrial partners. This modus operandi, as the focus of this study, is characterized more as mainstream activities.

Such mainstream activities involve the RCRC compound of the TTC. The NTI leaders and collaborators, with the occasional participation of researchers, will then detect the needs or opportunities of improving these activities to allow better institutional technology transfers. The suggested changes would, then, be sensed and provoke the change of the RCRC compound of the said dynamic capability.

The new RCRC compound, or the new TTC, will be codified so that the intentional actions for technology transfer can be kept continuous, predictable and standardized. Detecting, sensing, changing and codifying are the newstream procedure core, according to Lawson and Samson (2001), which allow renewing, recombining or reconfiguring the dynamic capacity. Moreover, the meta-routine comprises patent application, offers and technological negotiations and, finally, licensing contracts that generate income and royalties. All these TTC characteristics are also subject to the mainstream innovations and changes.

In addition to TTC characteristics and RCRC compound, we also found internal and external TTC development factors at the investigated institutions. That is, the environmental dynamism, either endogenous or exogenous to the institution, contributed to generate changes to the RCRC compound and, consequently, interfere in the onset, evolution or retrocession of the said dynamic capability.

In the case of internal factors, we identified, in both institutions, the action of leaders and inventor researchers, substantive capabilities, organizational knowledge, strategic management, project management, geographic location, the learning processes and operational processes. Meanwhile, the external factors regarded the intellectual anteriority, innovation, market, public policies and the society.

This study's findings lead to some contributions. The first was characterizing the TTC, that is, the TTC was distinguished from other capabilities, and its making was then made clear. Therefore, TTC was regarded as an RCRC compound set to transmit some technologic content from one organization to another. 
The second contribution resides in the fact that the very change of one capacity, as well as its compound, occurred by induction and influence of organizational factors, mainly by the intentionality of human actors. More specifically, those responsible for such dynamic attribute of the TTC were leaders, collaborators and researchers. In other words, people in the institutions who made it dynamic or regarded it as dynamic, i.e., the internal and external factors were not enough to found, sustain or make change a capability without the intentional participation of human actors.

Creating a TTC operational functioning framework in Brazilian public HEIs was the third contribution. We did not find models or frameworks in the technology transfer literature that adequately explained how it happens in Brazilian universities. In addition, we understand that the application of this framework, due to the general conceptualization, may be extended to other national and international institutions.

Such understanding regarding the last question is based on the fact that the existence of resources, competencies, routines, capabilities and some external factors capable of influencing the development dynamics of the technology transfer capability are common to the NTI, as well as to sectors analogous to them (e.g. TTO); however, spatial, social, economic and time singularity of the analysis occur. We can also find the very mainstream activities and the dynamic and intentional actions conducted by human actors to promote changes and innovations to the RCRC compound in any public higher education institution that possesses the formal processes of technology transfer.

Finally, we suggest new research that: a) allow validating and improving the framework herein proposed in other types of organizations, such as private firms, also involving other capabilities, as is the case of absorptive, innovative, relational and leadership capabilities; b) investigate, from a quantitative perspective, the relation between technology transfer and organization performance; c) create and validate a development scale of the technology transfer capability; and, d) analyze the behavior of the technology transfer dynamic capacity over time.

\section{REFERENCES}

ADES, C. Modelo de difusão da inovação para instituto de pesquisa no Brasil. 2013. 166 f. Tese. (Doutorado em Ciências) - Universidade de São Paulo (USP), São Paulo, 2013.

ADNER, R.; HELFAT, C. Corporate effects and dynamics managerial capabilities. Strategic Management Journal, v. 24, p. 1011-1025, 2003.

AMBROSINI, V.; BOWMAN, C. What are dynamics capabilities and are they a useful constructo in strategic management? International Journal of Management Reviews, v. 11, n. 1, p. 29-49, 2009.

AUGIER, M.; TEECE, D. J. Strategy as evolution with design: the foundations of dynamic capabilities and the role of managers in the economic system. Organization Studies, v. 29, n.8/9, p.1187-1208, 2008.

BARNEY, J. B. Firm resources and sustained competitive advantage. Journal of Management, v. 17, p. 99-120, 1991.

BERCOVITZ, J.; FELDMANN, M. Entpreprenerial universities and technology transfer: a conceptual framework for understanding knowledge-based economic development. The Journal of Technology Transfer, v. 31, p. 175-188, 2006.

BOEHM, D. N.; HOGAN, T. 'A jack of all trades': the role of PIs in the establishment and management of collaborative networks in scientific knowledge commercialisation. The Journal of Technology Transfer, $\mathrm{v}$. 39, p. 134-149, 2014.

BURAWOY, M.; BURTON, A.; FERGUSON, A. A.; FOX, K. J.; GAMSON, J.; GARTRELL, N.; HURST, L.; KURZMAN, C.; SALZINGER, L.; SCHIFFMAN, J.; UI, S. Ethnography unbound: power and resistance in the modern metropolis. Berkeley and Los Angeles, California: University of California Press, 1991.

BURAWOY, M. The extended case method: four countries, four decades, four great transformations, and one theoretical tradition. Berkeley and Los Angeles, California: University of California Press, 2009. 
BBR

16,1

13

BURREL, G.; MORGAN, G. Sociological paradigms and organisational analysis. London: Heinemann, 1979.

CADORI, A. A. A gestão do conhecimento aplicada ao processo de transferência de resultados de pesquisa de instituições federais de ciência e tecnologia para o setor produtivo: processo mediado pelo Núcleo de Inovação Tecnológica. 2013. 465 f. Tese. (Doutorado em Engenharia e Gestão do Conhecimento) Universidade Federal de Santa Catarina (UFSC), Florianópolis, 2013.

CARVALHO, I. V.; CUNHA, N. C. V. Proposta de um modelo de transferência de tecnologia para as universidades públicas brasileiras. In: CONGRESSO LATINO-IBEROAMERICANO DE GESTÃO DE TECNOLOGIA, 15., 2013, Porto. Anais eletrônicos... Porto: ALTEC, 2013. Disponível em: <http:// www.altec2013.org/programme_pdf/384.pdf > . Acesso em: 30 mai. 2015.

CLARIM, H. J. O patenteamento em uma instituição científica e tecnológica antes e depois da criação do Núcleo de Inovação Tecnológica: o caso do Instituto Nacional de Tecnologia. 2011. 108f. Dissertação. (Mestrado em Tecnologia) - Centro Federal de Educação Tecnológica Celso Suckow da Fonseca (CEFET/ RJ), Rio de Janeiro, 2011.

CLOSS, L. Q.; FERREIRA, G. C. A transferência de tecnologia universidade-empresa no contexto brasileiro: uma revisão de estudos científicos publicados entre os anos 2005 e 2009. Gestão \& Produção, v. 19, n. 2 , p. 419-432, 2012.

CLOSS, L. Q.; FERREIRA, G.; BRASIL, V.; SAMPAIO, C.; PERIN, M. What motivates brazilian academic researchers to transfer technology? Journal of Technology Management \& Innovation, v. 18, n. 4, p. 79-90, 2013.

COLLIS, D. J. Research note: how valuable are organizational capabilities? Strategic Management Journal, v. 15, p. 143-152, 1994.

COZZI, A.; JUDICE, V.; DOLABELA, F.; FILION, L. J. Empreendedorismo de base tecnológica. Spin-off: criação de novos negócios a partir de empresas constituídas, universidades e centros de pesquisa. Rio de Janeiro: Elsevier, 2008.

CYERT, R.; MARCH, J. G. A behavioral theory of the firm. 2. ed. Oxford: Blackwell Publishers Inc., 1992.

DANNEELS, E. The dynamics of product innovation and firm competences. Strategic Management Journal, v. 23, p. 1095-1121, 2002.

. Trying to become a different type of company: dynamic capability at Smith Corona. Strategic Management Journal, v. 32, p. 1-31, 2010.

DIAS, A. A.; PORTO, G. S. Gestão de transferência de tecnologia na Inova Unicamp. Revista de Administração Contemporânea, Rio de Janeiro, v. 17, n. 3, art. 1, p. 263-284, mai./jun. 2013.

. Como a USP transfere tecnologia? Organizações \& Sociedade, v. 21, n. 70, p. 489-507, 2014.

EISENHARDT, K. M.; MARTIN, J. A. Dynamic capabilities: what are they? Strategic Management Journal, v. 21, p. 1105-1121, 2000.

GADET, F.; HAK, T.; MARIANI, B. S. Por uma análise automática do discurso: uma introdução à obra de Michel Pêcheux. 3. ed. São Paulo: Ed. UNICAMP, 1997.

GARCIA, M. O.; GAVA, R. Gestão da propriedade intelectual como suporte à inovação tecnológica: o caso do Núcleo de Inovação Tecnológica da Universidade Federal de Viçosa. Revista de Design, Inovação e Gestão Estratégica, v. 3, n. 3, p. 1-24, dez. 2012.

GEBAUER, H. Exploring the contribution of management innovation to the evolution of dynamics capabilities. Industrial Marketing Management, v. 40, p. 1238-1250, 2011.

GOPALAKRISHNAN, S.; SANTORO, M. D. Distinguishing between knowledge transfer and technology transfer activities: the role of key organizational factors. IEEE Transactions on engineering management, v. 51, n. 1, feb., p. 57-69, 2004.

GODOI, C. K.; MATTOS, P. L. C. L. Entrevista qualitativa: instrumento de pesquisa e evento dialógico. In: GODOI, C. K.; BANDEIRA-DE-MELLO, R.; SILVA, A. A. A pesquisa qualitativa em estudos organizacionais: paradigmas, estratégias e métodos. São Paulo: Saraiva, 2010.

GRAY, D. E. Pesquisa no mundo real. 2. ed. Porto Alegre: Penso, 2012.

HELFAT, C. E.; FINKELSTEIN, S.; MITCHELL, W.; PETERAF, M.; SINGH, H.; TEECE, D. J.; WINTER, S. G. Dynamic capabilities: understanding strategic change in organizations. Oxford, UK: Blackwell Publishing Ltd., 2007.

HELFAT, C. E.; PETERAF, M. A. The dynamic Resource-Based View: capability lifecycles. Strategic Management Journal, v. 24, n. 10, p. 997-1010, 2003. 
HELLMANN, T. The role of patents for bridging the science to market gap. Journal of Economic Behavior \& Organization, v. 63, p. 624-647, 2007.

IVARSSON, M.; GORSCHEK, T. Technology transfer decision support in requirements engineering research: a systematic review of REj. Requirements Engineering, v. 14, n. 3, p. 155-175, 2009.

JAGODA, K.; MAHESHWARI, B.; LONSETH, R. Key issues in managing technology transfer projects: experiences from Canadian SME. Management Decision, v. 48, n. 3, p. 366-382, 2010.

KATHOEFER, D. G.; LEKER, J. Knowledge transfer in academia: an exploratory study on the not-inventedhere syndrome. The Journal of Technology Transfer, v. 37, p. 658-675, 2012.

KVALE, S.; BRINKMANN, S. Interviews: learning the craft of qualitative research interviewing. Thousand Oak (California): Sage, 2009.

LAWSON, B.; SAMSON, D. Developing innovation capability in organisations: a dynamics capabilities approach. International Journal of Innovation Management, v. 5, n. 3, p. 377-400, set. 2001.

MATHEWS, J. A.; HU, M-C. Enhancing the role of universities in building National Innovative Capacity in Asia: the case of Taiwan. World Development, v. 35, n. 6, p. 1005-1020, 2007.

McKELVIE, A.; DAVIDSSON, P. From resource base to dynamic capabilities: an investigation of new firms. British Journal of Management, v. 20, n. s1, p. S63-S80, 2009.

MERRIAM, S. B. Qualitative Research: a guide to design and interpretation. San Francisco: Jossey-Bass, 2009.

MILAGRES, R. Rotinas - uma revisão teórica. Revista Brasileira de Inovação, Campinas (SP), v. 10, n. 1, p. 161-196, jan./jun. 2011.

MINISTÉRIO DA CIÊNCIA, TECNOLOGIA E INOVAÇÃO (MCTI). Política de propriedade intelectual das instituições científicas e tecnológicas do Brasil: relatório Formict 2014. Brasília: Ministério da Ciência, Tecnologia e Inovação, 2015.

NELSON, R. R.; WINTER, S. G. Uma Teoria Evolucionária da Mudança Econômica. Campinas: Unicamp, 2005.

PAVLOU, P. A.; EL SAWY, O. A. Understanding the elusive black box of dynamic capabilities. Decision Sciences, v. 42, n. 1, p. 239-273, 2011.

PENROSE, E. A Teoria do Crescimento da Firma. Campinas: Editora da Unicamp, 2006.

RANKING UNIVERSITÁRIO FOLHA (RUF). Folha de São Paulo, São Paulo, 2015. Disponível em: $<$ http://ruf.folha.uol.com.br/2015/ranking-de-universidades/>. Acesso em: 31 set. 2016.

RINDOVA, V.; TAYLOR, M. S. Dynamic capabilities as macro and micro organizational evolution. 2002. Disponível em: <http://bus8020kelly.alliant.wikispaces.net/file/view/Dynamic\%20Capabilities\%20 as\%20Micro\%20Macro.pdf/32941769/Dynamic\%20Capabilities\%20as\%20Micro\%20Macro.pdf>. Acesso em: 02 mai. 2015.

ROGERS, E. M.; TAKEGAMI, S.; YIN, J. Lessons learned about technology transfer. Technovation, v. 21, n. 4 , p. 253-261, 2001.

ROMME, A. G. L.; ZOLLO, M.; BERENDS, P. Dynamic capabilities, deliberate learning and environmental dynamism: a simulation model. Industrial and Corporate Change, v. 19, n. 4, p. 1271-1299, 2010.

SANTOS, M. E. R.; TOLEDO, P. T. M.; LOTUFO, R. A. Transferência de tecnologia: estratégias para a estruturação e gestão de Núcleos de Inovação Tecnológica. Campinas, SP: Komedi, 2009.

SCIMAGO INSTITUTIONS RANKINGS (SIR). SIR Iber 2015 Rank: Output 2009-2013. SCImago Research Group, Data Source: Scopus. Disponível em: $<$ http://www.scimagoir.com/pdf/iber_new/SIR\%20Iber\%20 2015\%20HE.pdf>. Acesso em: 31 set. 2016.

SCHUMPETER, J. A. Capitalismo, socialismo e democracia. Rio de Janeiro: Editora Fundo de Cultura, 1961.

SZULANSKI, G. The process of knowledge transfer: a diachronic analysis of stickiness. Organizational Behavior and Human Decision Processes, v. 82, n. 1, p. 9-27, 2000.

TAKAHASHI, V. P.; SACOMANO, J. B. Proposta de um modelo conceitual para análise do sucesso de projetos de transferência de tecnologia: estudo em empresas farmacêuticas. Gestão \& Produção, v. 9, n. 2, p. 181-200, 2002.

TEECE, D. J. Explicating dynamics capabilities: the nature and microfoundations of (sustainable) enterprise performance. Strategic Management Journal, v. 28, p. 1319-1350, 2007.

TEECE, D. J.; PISANO, G.; SHUEN, A. Dynamic capabilities and strategic management. Strategic Management Journal, v. 18, n. 7, p. 509-533, 1997. 
TONDOLO, V. A. G.; BITENCOURT, C. C. Compreendendo as Capacidades Dinâmicas a Partir de Seus Antecedentes, Processos e Resultados. Brazilian Business Review, v. 11, n. 5, p. 124 - 147, set.-out. 2014.

WANG, G. L.; AHMED, P. K. Dynamic capabilities: a review and research agenda. International Journal of Management Reviews, v. 9, n. 1, p. 31-51, 2007.

WERNERFELT, B. A Resource-Based View of the firm. Strategic Management Journal, v. 5, n. 2, p. 171180, apr./jun. 1984.

WILDEN, R.; GUDERGAN, S. P.; NIELSEN, B. B.; LINGS, I. Dynamic capabilities and performance: strategy, structure and environment. Long Range Planning, v. 46, n. 1, p. 72-96, 2013.

WILLIAMSON, O. E. The Economic Institutions of Capitalism: firms, markets, relational contracting. New York: Free Press, 1985.

WINTER, S. G. Understanding dynamics capabilities. Strategic Management Journal, v. 24, p. 991-996, 2003.

YOUNG, T. A. Academic technology transfer. International Journal of Intellectual Property-Law, Economy and Management, v. 1, n. 1, p. 13-18, 2005.

ZAHRA, S.; SAPIENZA, H.; DAVIDSSON, P. Entrepreneurship and dynamics capabilites: a review, model and research agenda. Journal of Management Studies, v. 43, p. 917-955, 2006.

ZOLLO, M.; WINTER, S. Deliberate learning and the evolution of dynamics capabilities. Organization Science, v. 13, p. 339-351, 2002.

ZOTT, C. Dynamic capabilities and the emergence of intraindustry differential firm performance: insights from a simulation study. Strategic Management Journal, v. 24, n. 2, p. 97-125, 2003. 